\title{
PENGEMBANGAN PERANGKAT PEMBELAJARAN PROBLEM BASED LEARNING DENGAN PENDEKATAN SAINTIFIK UNTUK MELATIHKAN KETERAMPILAN BERPIKIR KRITIS MAHASISWA
}

\author{
Adi Candra Kusuma ${ }^{1}$, Dwi Setia Mujiono ${ }^{2}$ \\ 1,2Politeknike Harapan Bersama \\ Corresponding Author: candraraden45@gmail.com ${ }^{1}$
}

\begin{abstract}
The research aims to obtain the validity of Problem Based Learning teaching instruments (including lesson plan, textbooks, student worksheets and test for critical thinking skills) through a scientific approach. This type of quantitative research, Quantitative data obtained from the average results of the recapitulation of the validation of experts and colleagues then as an evaluation given through descriptive advice, with the method of collecting observational data, questionnaires and interviews. Data analysis techniques use content and construct validity specified by several experts in the appropriate fields. Construct validation by 2 expert validators and 3 peer validators. The results of the average validation of the learning device recapitulation were obtained RPS (4.00), RPP (4.10), textbooks (4.03), Student Worksheets (4.01) and Tests for students' critical thinking skills (4.00) in the scale range 5 with the title of good to be used as a research instrument. Each of the results of the validation construct of the learning device is given suggestions to be improved before it is used in learning
\end{abstract}

Keywords: Validation; Problem Based Learning; Scientific; Critical thinking skills

How to cite: Kusuma, A. C. \& Mujiono, D. S. (2019). Pengembangan Perangkat Pembelajaran Problem Based Learning dengan Pendekatan Saintifik untuk Melatihkan Keterampilan Berpikir Kritis Mahasiswa. JRPM (Jurnal Review Pembelajaran Matematika), 4(2), 102-114.

\section{PENDAHULUAN}

Keterampilan berpikir merupakan keterampilan dalam menggabungkan sikap, pengetahuan, dan keterampilan yang memungkinkan seseorang untuk dapat membentuk lingkungannya agar lebih efektif. Keterampilan berpikir dapat dibedakan menjadi berpikir kritis dan berpikir kreatif (Anjarsari, 2014). Berpikir kritis merupakan berpikir yang terjadi dalam sistem kognitif dengan membandingkan beberapa pengetahuan yang sudah ada dalam pikiran yang bertujuan untuk menyelesaikan suatu permasalahan dengan memutuskan pengetahuan yang lebih tepat digunakan untuk memecahkan masalah. Indikator keterampilan berpikir kitis pada penelitian ini meliputi: 1) mampu menganalisis argumen, 2) mampu mengevaluasi informasi, 3) mampu mensintesis bukti, dan 4) mampu menarik kesimpulan. Matematika sendiri merupakan salah satu keilmuan yang dapat membantu menumbuhkan cara berpikir kritis, logis dan sistematis.

Banyaknya konsep yang abstrak dalam pembelajaran matematika mengakibatkan 
mahasiswa beranggapan matematika itu sulit. Mahasiswa baru mampu mempelajari dan menghafal fakta, konsep, prinsip, hukum, teori dan gagasan inovatif lainnya pada tingkat ingatan, mereka belum dapat menggunakan dan menerapkannya secara efektif dalam pemecahan masalah sehari-hari yang kontekstual (Kusuma, 2017). Hasil observasi proses belajar mengajar yang dilakukan di Program Studi D3 Teknik Komputer Politeknik Harapan Bersama sekarang ini masih menggunakan metode konvensional dalam penyampaian pembelajarannya. Metode pembelajaran konvensional meliputi berbagai metode yang berpusat pada dosen bidang studi. Mahasiswa kurang dilatih berpikir kritis untuk menyelesaikan soal dengan penyelesaian sendiri. Mahasiswa hanya mampu menyelesaikan soal yang serupa dengan contoh yang diberikan dosen sehingga jika diberikan soal yang lebih kompleks mahasiswa mengalami kesulitan.

Kemampuan berpikir kritis ini dapat dikembangkan melalui pembelajaran dimana masalah dihadirkan di kelas dan mahasiswa diminta untuk menyelesaikannya dengan segala pengetahuan dan keterampilan yang mereka miliki. Pembelajaran bukan lagi sebagai "transfer of knowledge", tetapi mengembangkan potensi mahasiswa secara sadar melalui kemampuan yang lebih dinamis dan aplikatif. Seharusnya, pembelajaran di dalam kelas menjadikan mahasiswa sebagai pusat pembelajaran sehingga mahasiswa dapat aktif dalam membangun pengetahuannya sendiri. Hal ini sejalan dengan pendapat Bruner (1999) bahwa belajar adalah proses aktif dimana mahasiswa membangun pengetahuan berdasarkan pengalaman yang sudah dimilikinya. Oleh karena itu diperlukan suatu model pembelajaran yang berpusat pada mahasiswa dan dapat memberikan pengalaman mahasiswa dalam menyelesaikan soal matematika. Satu di antara model pembelajaran yang dapat diterapkan adalah model pembelajaran Problem Based Learning (PBL).

Problem Based Learning (PBL) memberikan peluang bagi siswa untuk melakukan penelitian dengan berbasis masalah nyata dan autentik. Model pembelajaran PBL sebaiknya memenuhi kriteria: kompleks, struktur tidak jelas, terbuka dan autentik. Prinsip-prinsip proses pembelajaran PBL yang harus diperhatikan meliputi konsep dasar (basic concept), pendefinisian masalah (defining the problem), pembelajaran mandiri (self learning), dan pertukaran pengetahuan (exchange knowledge). Sistem penilaian pada PBL dilakukan dengan memadukan tiga aspek pengetahuan (knowledge), kecakapan (skill), dan sikap (attitude). Penilaian terhadap penguasaan pengetahuan yang mencakup seluruh kegiatan pembelajaran yang dilakukan dengan ujian akhir semester (UAS), ujian tengah semester (UTS), kuis, PR, dokumen, dan laporan kemudian dilakukan rekapitulasi. Penilaian terhadap 
kecakapan dapat diukur dari penguasaan alat bantu pembelajaran, baik software, hardware, maupun kemampuan perancangan dan pengujian. Sedangkan penilaian terhadap sikap dititikberatkan pada penguasaan soft skill, yaitu keaktifan dan partisipasi dalam diskusi, kemampuan bekerjasama dalam tim, dan kehadiran dalam pembelajaran. Bobot penilaian untuk ketiga aspek tersebut ditentukan oleh pendidik yang bersangkutan ketika kontrak perkuliahan.

Selain menggunakan model PBL, untuk menciptakan lingkungan belajar yang kondusif dalam melatih kemampuan berpikir kritis siswa akan digunakan pendekatan saintifik. Alamsyah (2016) menjelaskan bahwa pendekatan saintifik meliputi kegiatan mengamati, menanya, mengumpulkan informasi, mengasosiasi dan mengkomunikasikan. Kegiatan mengamati merupakan kegiatan belajar yang dapat dilakukan peserta didik antara lain dengan cara membaca, mendengar, menyimak, melihat (dengan atau tanpa alat). Kegiatan menanya dapat dilakukan peserta didik dengan cara mengajukan pertanyaan tentang informasi apa yang tidak dipahami dari apa yang diamati atau pertanyaan untuk memperoleh informasi tambahan tentang apa yang sedang mereka amati. Sedangkan kegiatan mengumpulkan informasi dapat dilakukan secara eksperimen, membaca beragam sumber informasi lainnya selain yang terdapat pada buku teks, mengamati objek, mengamati kejadian, melakukan aktivitas tertentu, hingga berwawancara dengan seorang nara sumber. Kegiatan mengasosiasi, dengan melakukan pengolahan informasi mulai dari beragam informasi yang memperdalam dan memperluas informasi hingga informasi yang saling mendukung, bahkan yang berbeda atau bertentangan. Kegiatan mengkomunikasikan, dengan memberikan pengalaman belajar untuk melakukan kegiatan belajar berupa menyampaikan hasil pengamatan yang telah dilakukannya, kesimpulan yang diperolehnya berdasarkan hasil analisis, dilakukan baik secara lisan, tertulis, atau cara-cara dan media lainnya.

Pembelajaran dapat berjalan baik didukung dengan kelengkapan instrumen atau perangkat penunjang. Perangkat yang telah disiapkan dimaksudkan untuk mencapai tujuan pembelajaran yang diinginkan pendidik, sehingga perlu dilakukan validitas perangkat pembelajaran. Perangkat pembelajaran yang dikembangkan dikatakan valid jika perangkat itu memenuhi kriteria validasi isi dan konstruk yang ditetapkan beberapa ahli pada bidang yang sesuai. Validasi isi berarti terdapat konsistensi secara internal antara komponenkomponen dalam perangkat pembelajaran yang disusun, sedangkan validitas konstruk berarti perangkat pembelajaran yang dikembangkan didasarkan pada rasional teoritis yang 
kuat Sugiyono (2008). Dalam penelitian ini perangkat pembelajaran yang dikembangkan, yaitu: 1) Rencana Pembelajaran Semester (RPS), 2) Rencana Pelaksanaan Pembelajaran (RPP), 3) buku ajar, 4) Lembar Kerja Mahasiswa (LKM), dan 5) soal tes kemampuan keterampilan berpikir kritis mahasiswa.

\section{METODE PENELITIAN}

Jenis penelitian ini menggunakan penelitian kuantitatif dengan didukung data-data kualitatif. Data kuantitatif yang diperoleh dari hasil rata-rata rekapitulasi validasi ahli dan teman sejawat kemudian sebagai evaluasi yang diberikan melalui saran secara deskriptif. Perangkat pembelajaran yang dilakukan uji validitas pada mata kuliah Matematika Teknik dengan materi Statistika di Prodi Diploma III Teknik Komputer di Politeknik Harapan Bersama Tahun Akademik 2018/2019. Dengan teknik pengumpulan data menggunakan wawancara, kuisioner dan observasi.

Pengembangan perangkat pembelajaran menggunakan model umum pemecahan masalah bidang pendidikan yang dikemukakan Plomp dalam Rochmad (2012) yang terdiri dari fase investigasi awal (prelimenary investigation), fase desain (design), fase realisasi/konstruksi (realization/construction), fase tes, evaluasi dan revisi (test, evaluation and revision) dan implementasi (implementation). Akan tetapi pada penelitian ini hanya sampai fase evaluasi dan revisi (test, evaluation and revision) tanpa melakukan fase implementasi (implementation).

Pada fase investigasi awal (prelimenary investigation) dilakukan kegiatan mengidentifikasi informasi dari beberapa artikel, buku dan jurnal yang berkaitan dengan penelitian yang dilaksanakan sebagai landasan dalam kajian teori, melakukan studi pendahuluan pada subjek penelitian dan menganalisis hasil tersebut, mendefinisikan batasan masalah dari permasalahan yang akan diukur dan merencanakan kegiatan lanjutan dalam menentukan kompetensi yang akan dicapai. Secara ringkas identifikasi analisis kebutuhan atau analisis masalah kajian meliputi analisis kurikulum, analisis teori-teori belajar, analisis karakter mahasiswa, dan kompetensi yang harus dicapai.

Fase desain (design) bertujuan untuk mendapatkan rancangan awal dari perangkat pembelajaran yang akan dikembangkan, memberikan gambaran kepada dosen bagaimana dan apa yang harus dilakukan pada saat pembelajaran, merancang sistem pendukung yang akan digunakan pada saat penelitian dan merancang dampak pembelajaran. Selanjutnya fase realisasi/konstruksi (realization/ construction), terdiri dari kegiatan-kegiatan sebagai lanjutan dari kegiatan pada fase desain seperti menyusun instrumen meliputi RPS, RPP, buku ajar, LKM, 
tes kemampuan kemampuan keterampilan berpikir kritis mahasiswa, keterlaksanaan RPP, respon siswa dan lembar validasi perangkat pada materi statistika pembelajaran Problem Based Learning dengan pendekatan saintifik disebut draf 1, kemudian menyusun reaksi dari pembelajaran yang dilaksanakan, menentukan sistem pendukung pembelajaran, dan menyusun sistem pembelajaran Problem Based Learning dengan pendekatan saintifik.

Pada fase terakhir yaitu tes, evaluasi dan revisi (test, evaluation and revision), dilakukan untuk memperoleh data hasil ujicoba instrumen tes keterampilan berpikir kritis mahasiswa yang mencakup data validitas soal, reliabilitas soal, tingkat kesukaran soal dan daya beda soal. Berdasarkan data yang terkumpul dapat ditentukan pemecahan mana yang memuaskan dan mana yang masih perlu dikembangkan. Ini berarti kegiatan suplemen mungkin diperlukan dalam fase-fase sebelumnya, disebut siklus balik (feedback cycle). Siklus diulang-ulang sampai pemecahan yang diinginkan tercapai. Pada tahap ini juga dilakukan validasi perangkat dan ujicoba terbatas untuk mendapatkan perangkat praktis dan pembelajaran yang efektif dengan uraian seperti validasi perangkat dan ujicoba terbatas. Pada tahap ini dilakukan kegiatan validasi dan evaluasi perangkat pembelajaran oleh ahli dan teman sejawat yang disebut dengan validator. Kegiatan ini bertujuan untuk menentukan apakah draf 1 perangkat pembelajaran yang disusun valid. Langkah yang dilakukan yaitu validasi draf 1, analisis hasil validasi dan revisi. Apabila hasil analisis dari validator terhadap draf 1 tanpa revisi, atau sedikit revisi maka dilanjutkan dengan ujicoba terbatas draf 1 . Namun bila hasil analisis pertimbangan validator terhadap draf 1 perlu direvisi, maka diadakan revisi sehingga mendapatkan draf 2 dan seterusnya sehingga berakhir dengan hasil analisis validator terhadap draf yang tanpa revisi atau sedikit revisi. 


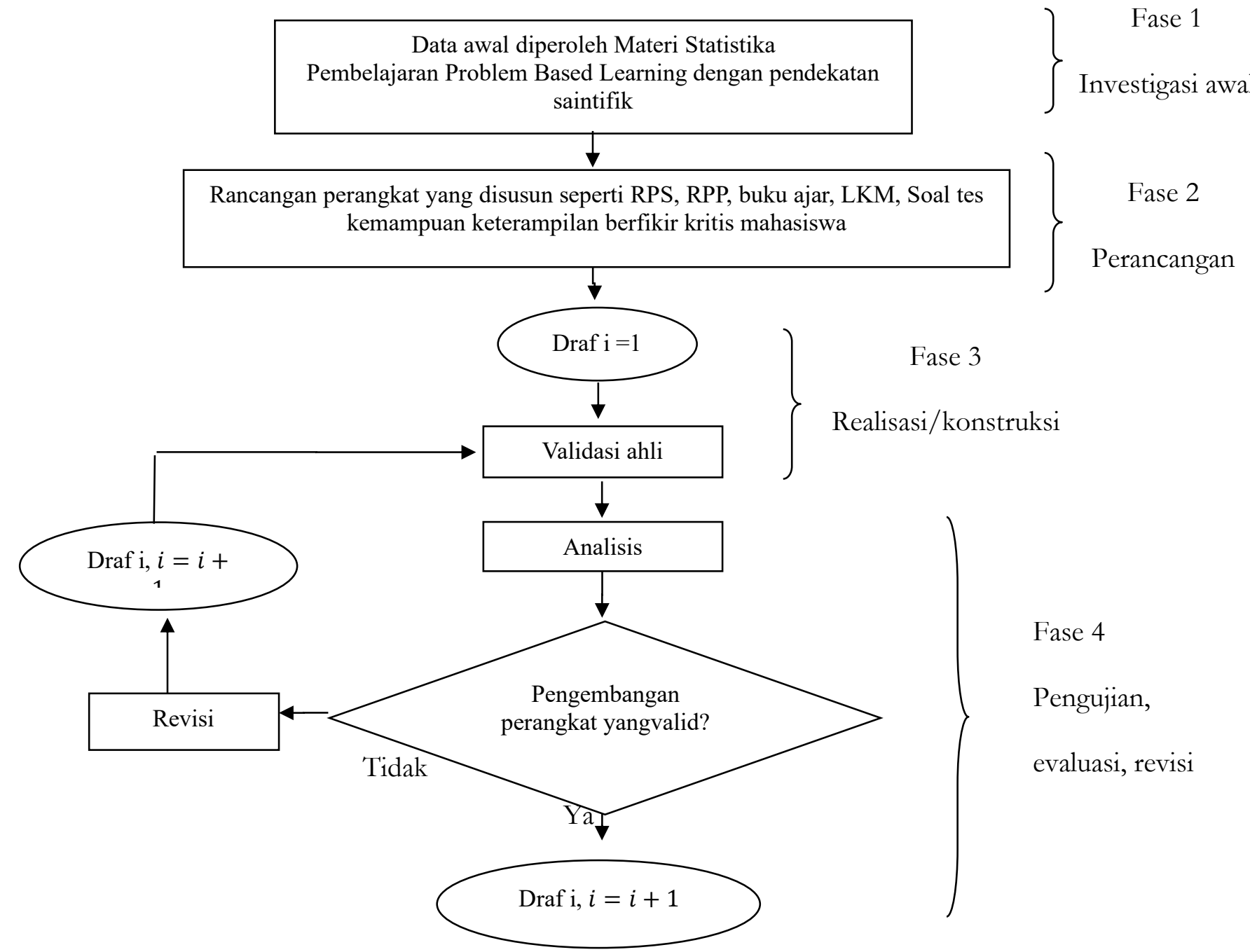

Keterangan:

Gambar 1. Alur Pengembangan Perangkat Model Plomp (Rochmad, 2012)

$\begin{array}{ll}\square & : \text { Kegiatan yang dilakukan di dalam penelitian } \\ & : \text { Urutan Alur Kegiatan } \\ & : \text { Hasil Kegiatan }\end{array}$

Data yang ada pada lembar validasi, dari penilaian masing-masing validator terhadap perangkat pembelajaran, dianalisis dan diolah secara deskriptif berdasarkan rata-rata skor. Deskripsi tentang rata-rata skor dari tiap-tiap perangkat pembelajaran digunakan skala Likert seperti tampak pada Tabel 1 berikut.

Tabel 1. Kriteria Perangkat Pembelajaran

\begin{tabular}{cc}
\hline Kriteria & Keterangan \\
\hline $1,00 \leq P \leq 1,80$ & tidak baik \\
$1,80<P \leq 2,60$ & kurang baik \\
$2,60<P \leq 3,40$ & cukup baik \\
$3,40<P \leq 4,20$ & Baik \\
$4,20<P \leq 5,00$ & sangat baik \\
\hline
\end{tabular}


Setiap perangkat pembelajaran dapat digunakan jika minimal termasuk dalam kriteria baik.

\section{HASIL DAN PEMBAHASAN}

Pengembangan perangkat yang digunakan berdasarkan pada Model Plomp yang telah dimodifikasi dengan menyesuaikan pembelajaran yang digunakan yaitu Problem Based Learning dengan pendekatan saintifik. Dilakukan penyederhanaan dari lima fase kegiatan menjadi empat fase kegiatan tanpa dilakukan fase yang kelima yaitu fase implementasi. Hasil modifikasi pengembangan perangkat meliputi a) fase investigasi awal (prelimenary investigation), b) fase desain (design), c) fase realisasi/konstruksi (realization/construction), dan d) fase tes, evaluasi dan revisi (test, evaluation and revision).

Fase investigasi awal (prelimenary investigation) merupakan kegiatan mengidentifikasi informasi dari beberapa artikel, buku dan jurnal yang berkaitan dengan penelitian yang dilaksanakan sebagai landasan dalam kajian teori, melakukan studi pendahuluan pada subjek penelitian dan menganalisis hasil tersebut, mendefinisikan batasan masalah dari permasalahan yang akan diukur dan merencanakan kegiatan lanjutan dalam menentukan kompetensi yang akan dicapai. Secara ringkas identifikasi analisis kebutuhan atau analisis masalah kajian meliputi a) analisis kurikulum yang terdiri dari analisis materi, analisis perangkat RPS sesuai dengan panduan KKNI, RPP dan bahan ajar; b) analisis teori-teori belajar, pada tahap ini telaah teori-teori pembelajaran yang mendasari model sehingga diperoleh deskripsi pola pembelajaran yang ideal. Teori belajar yang diambil adalah teori Piaget, teori konstruktivisme, dan teori Gagne; c) analisis karakter mahasiswa, meliputi kemampuan matematika yang dimiliki, sesuai dengan rancangan bahan pelajaran dan sikap terhadap topik pembelajaran dan kompetensi yang harus dicapai. Hasil wawancara dengan mahasiswa secara umum disimpulkan sebagai berikut: 1) mahasiswa dalam menerima materi mengalami kesulitan pemahaman dari dosen, 2) kesulitan menentukan rumus matematika yang akan digunakan dalam menyelesaikan masalah, 3) kurang merata (kurang maksimal) dalam memberikan kesempatan mahasiswa untuk bertanya dan menyimpulkan, 4) saat pembelajaran sering dijumpai dosen bahwa mahasiswa berkemampuan rendah langsung menyatakan sulit, kebingungan jika menemui masalah yang tidak sesuai dengan contoh yang diajarkan, 5) kurangnya informasi/ pengetahuan akan kemanfaatan statistika di kehidupan sehari-hari, 6) mahasiswa lebih menyukai buku ajar atau LKM dengan tulisan sederhana tapi mudah dipahami, dan 7) mahasiswa lebih suka pembelajaran yang berkelompok.

Fase desain (design), pada perencanaan pembuatan RPP disesuaikan dengan pendekatan 
saintifik yang meliputi mengamati, menanya, mengumpulkan informasi, mengasosiasi dan mengkomunikasikan. Kegiatan-kegiatan pada tahap ini antara lain merancang dan menyusun kriteria penyusunan tes, media pembelajaran, dan format perangkat pembelajaran. Deskripsi kegiatan pada tahap perancangan meliputi kriteria penyusunan tes. Berdasarkan hasil analisis materi, analisis tugas dan spesifikasi tujuan pembelajaran. Rancangan tes yang dikembangkan dalam penelitian ini adalah Tes Kemampuan Keterampilan Berpikir Kritis Mahasiswa (TKKBKM) materi statistika dalam rangka mengukur ketercapaian tujuan pembelajaran. Tes disusun berdasarkan indikator pencapaian kompetensi yang telah dirumuskan dengan tahapan penyusunan kisi-kisi soal, menyusun butir soal dan membuat kriteria penilaian. Penilaian pada tes ini berdasarkan indicator berpikir kritis diantaranya kemampuan perhitungan menggunakan rumus, kemampuan menggeneralisasikan/menarik kesimpulan, menggunakan hubungan antar konsep dan menyusun pembuktian. Ujicoba soal (TKKBKM) terdiri dari 15 soal dan setelah melakukan analisis butir soal diperoleh 13 soal valid untuk digunakan dalam mengukur kemampuan keterampilan berpikir kritis mahasiswa, tetapi soal yang akan dipakai yaitu 4 soal melihat durasi alokasi waktu 6 yang diberikan hanya 60 menit. Tes yang telah disusun, selanjutnya dilengkapi dengan kunci jawaban dan norma penilaian. Besar kecilnya pembobotan skor setiap butir soal disesuaikan dengan banyaknya langkah penyelesaian soal.

Kegiatan lanjutan setelah perancangan dan penyusunan kriteria penyusunan tes, media pembelajaran, format perangkat pembelajaran adalah merancang instrumen penilaian perangkat pembelajaran yang terdapat pada fase realisasi/konstruksi (realization/construction). Instrumen-instrumen penilaian dibuat terdiri dari lembar validasi RPS, lembar validasi RPP, lembar validasi buku siswa, validasi LKM dan validasi TKKBKM dan disertai petunjuk penilaian. Instrumen validasi perangkat yang akan digunakan untuk menilai perangkat pembelajaran terlebih dahulu dikonsultasikan kepada dosen berulang kali. Bimbingan validasi perangkat dilakukan beberapa kali untuk menilai perangkat pembelajaran yang telah dikembangkan sampai expert menyatakan lembar validasi dapat digunakan. Sistem pendukung keberhasilan pembelajaran di antaranya tempat duduk di kelas diatur berkelompok yang beranggotakan 4-5 siswa.

Fase selanjutnya adalah fase tes, evaluasi dan revisi (test, evaluation and revision), kegiatan yang dilakukan pada tahap ini yaitu validasi ahli, ujicoba butir soal TKKBKM terhadap pelaksanaan model pembelajaran Problem Based Learning dengan pendekatan saintifik. Hasil dari validasi ahli digunakan untuk merevisi dan memperbaiki draf 1 menjadi draf 2. 
Ujicoba butir soal TKKBKM dilakukan kepada 32 mahasiswa untuk mengetahui kevalidan, reliabilitas, tingkat kesukaran dan daya beda soal.

Hasil validasi ahli dilakukan untuk melihat validasi isi perangkat yang telah disusun berdasarkan langkah-langkah model pembelajaran Problem Based Learning dengan pendekatan saintifik. Hasil validasi perangkat pembelajaran digunakan untuk menentukan apakah perangkat pembelajaran dapat dipakai atau tidak dalam pembelajaran. Jumlah validator perangkat pembelajaran yaitu lima validator yang terdiri dari dua dosen dengan jabatan lektor dan tiga ahli dari rekan-rekan sejawat. Rekapitulasi hasil validasi ahli terhadap perangkat pembelajaran dapat dilihat pada Tabel 2 berikut.

Tabel 2. Rekapitulasi Hasil Validasi Perangkat

\begin{tabular}{lcccccccc}
\hline \multirow{2}{*}{ Perangkat } & \multicolumn{9}{c}{ Validator } & \multirow{2}{*}{ Rata-rata } & \multirow{2}{*}{ Keterangan } & \multirow{2}{*}{ Kriteria } \\
\cline { 2 - 5 } & I & II & III & IV & V & & Valid & Baik \\
\hline RPS & 3.88 & 4.12 & 3.9 & 4.1 & 4 & 4.00 & Valid & Baik \\
RPP & 4.19 & 3.9 & 3.7 & 4.48 & 4.3 & 4.10 & Valid & Baik \\
Buku Ajar & 3.92 & 3.85 & 3.85 & 4.62 & 4.54 & 4.03 & Valid & Baik \\
LKM & 4.14 & 3.21 & 3.79 & 4.50 & 4.30 & 4.01 & Valid & Baik \\
TKKBKM & 4.1 & 4 & 4.1 & 3.9 & 4.4 & 4.00 & & \\
\hline
\end{tabular}

Penilaian RPS dilakukan berdasarkan komponen pengembangan RPS yang dibuat menggunakan pembelajaran Problem Based Learning dengan pendekatan saintifik. Berdasarkan Tabel 3 tampak bahwa nilai rata-rata validasi terhadap draf 1 RPS adalah 4,00 yang artinya draf 1 RPS memperoleh kategori baik, dengan simpulan yang diberikan valid dan RPS dapat digunakan. Selanjutnya disusun rekapitulasi saran dan masukan validator untuk perbaikan RPS seperti disajikan pada Tabel 3 Revisi RPS dilakukan berdasarkan saran dan masukan validator.

Tabel 3. Saran Validator mengenai RPS

\begin{tabular}{|c|c|c|c|}
\hline No & Aspek yang dinilai & Catatan & Revisi \\
\hline 1 & $\begin{array}{l}\text { Indikator pencapaian } \\
\text { kompetensi }\end{array}$ & $\begin{array}{l}\text { Pengembangan kemampuan } \\
\text { penalaran diupayakan melatih } \\
\text { logika dan analisis }\end{array}$ & $\begin{array}{l}\text { Pada penilaian soal } \\
\text { memperhatikan kemampuan } \\
\text { penalaran menyesuaikan dengan } \\
\text { indikator penalaran }\end{array}$ \\
\hline 2 & Kegiatan pembelajaran & $\begin{array}{l}\text { Disesuaikan dengan model } \\
\text { pembelajaran Problem Based } \\
\text { Learning dengan pendekatan } \\
\text { saintifik }\end{array}$ & $\begin{array}{l}\text { Menyesuaikan langkah-langkah } \\
\text { model pembelajaran Problem } \\
\text { Based Learning dengan } \\
\text { pendekatan saintifik sesuai } \\
\text { dengan sintaknya }\end{array}$ \\
\hline 3 & Ejaan dan struktur kalimat & Konsisten penulisan & $\begin{array}{l}\text { Merevisi penulisan yg salah } \\
\text { kemudian mengecek penulisan } \\
\text { yang tidak konsisten }\end{array}$ \\
\hline
\end{tabular}

Penilaian RPP berdasarkan pada komponen pengembangan RPP yang dibuat menggunakan pembelajaran Problem Based Learning dengan pendekatan saintifik. Tabel 3 
menunjukkan bahwa nilai rata-rata validasi terhadap draf 1 RPP adalah 4,10 artinya draf 1 RPP memperoleh kategori baik, dengan simpulan valid dan perangkat RPP dapat digunakan. Berdasarkan rekapitulasi saran dan masukan validator seperti tampak pada Tabel 4, selanjutnya dilakukan revisi terhadap perbaikan RPP.

Tabel 4. Saran Validator Mengenai RPP

\begin{tabular}{|c|c|c|c|}
\hline No & Aspek yang dinilai & Catatan & Revisi \\
\hline 1 & $\begin{array}{l}\text { Norma penilaian } \\
\text { pendukung pengukuran } \\
\text { sikap dan keaktifan } \\
\text { Mahasiswa }\end{array}$ & $\begin{array}{l}\text { Skor penilaiannya dibuat rubrik } \\
\text { menggunakan kolom }\end{array}$ & $\begin{array}{l}\text { Merevisi skor penilaian dengan } \\
\text { menggunakan rubrik kolom }\end{array}$ \\
\hline \multirow[t]{3}{*}{2} & Kegiatan pembelajaran & $\begin{array}{l}\text { Kurikulum KKNI menggunakan } \\
\text { pendekatan saintifik sehingga } \\
\text { perlu dicantumkan ke dalam RPP }\end{array}$ & $\begin{array}{l}\text { Menyesuaikan aturan } \\
\text { pembuatan RPP sesuai dengan } \\
\text { kurikulum KKNI yaitu } \\
\text { pendekatan saintifik }\end{array}$ \\
\hline & & $\begin{array}{l}\text { Sintak pembelajaran saintifik } \\
\text { belum tampak pada RPP }\end{array}$ & $\begin{array}{l}\text { Menyesuaikan sintak saintifik ke } \\
\text { dalam pembelajaran PBL }\end{array}$ \\
\hline & & $\begin{array}{l}\text { Kegiatan utama dari model ini } \\
\text { adalah PBL bukan saintifik }\end{array}$ & $\begin{array}{l}\text { Merevisi kegiatan PBL yang } \\
\text { mencangkup saintifik }\end{array}$ \\
\hline
\end{tabular}

Penilaian buku ajar berdasarkan pada komponen pengembangan buku ajar yang dibuat menggunakan pembelajaran problem based learning dengan pendekatan saintifik. Tabel 3 menunjukkan bahwa nilai rata-rata validasi terhadap draf 1 buku ajar adalah 4,03 artinya draf 1 buku ajar memperoleh kategori baik, dengan simpulan valid dan dapat digunakan pada materi statistika. Kemudian validator memberikan saran untuk perbaikan perangkat pembelajaran ke depannya. Berdasarkan rekapitulasi saran dan masukan validator seperti tampak pada Tabel 5, selanjutnya dilakukan revisi terhadap perbaikan buku ajar agar sesuai dengan tujuan pembelajaran yang dikehendaki.

Tabel 5. Saran Validator Mengenai Buku Ajar

\begin{tabular}{llll}
\hline No & Aspek yang dinilai & \multicolumn{1}{c}{ Catatan } & \multicolumn{1}{c}{ Revisi } \\
\hline 1 & Kegiatan pembelajaran & $\begin{array}{l}\text { Kegiatan saintifik belum } \\
\text { nampak/terlihat. }\end{array}$ & $\begin{array}{l}\text { Merevisi di dalam buku } \\
\text { mahasiswa dengan mencangkup } \\
\text { saintifik }\end{array}$ \\
& Materi pelajaran & $\begin{array}{l}\text { Pengambilan sampel disertakan } \\
\text { teknik sampling, }\end{array}$ & $\begin{array}{l}\text { Merevisi dengan } \\
\text { mencantumkan materi teknik } \\
\text { pengambilan sampel } \\
\end{array}$ \\
& Latihan soal & $\begin{array}{l}\text { Buatlah soal tantangan yang } \\
\text { tidak sama dengan soal latihan }\end{array}$ & $\begin{array}{l}\text { latihan soal tidak sama tetapi } \\
\text { tanpa merubah indikator } \\
\text { pencapaian }\end{array}$ \\
\hline
\end{tabular}

Penilaian Lembar Kerja Mahasiswa (LKM) berdasarkan pada komponen pengembangan Lembar Kerja Mahasiswa (LKM) yang dibuat menggunakan pembelajaran Problem Based Learning dengan pendekatan saintifik. Tabel 2 menunjukkan bahwa nilai ratarata validasi terhadap draf 1 Lembar Kerja Mahasiswa (LKM) adalah 4,01 artinya draf 1 
Lembar Kerja Mahasiswa (LKM) memperoleh kategori baik, dengan simpulan valid dan dapat digunakan pada materi statistika. Kemudian validator memberikan saran untuk perbaikan perangkat pembelajaran ke depannya. Rekapitulasi saran validator selanjutnya melakukan revisi terhadap perbaikan Lembar Kerja Mahasiswa (LKM). Berdasarkan rekapitulasi saran dan masukan validator seperti tampak pada Tabel 6, selanjutnya dilakukan revisi terhadap perbaikan LKM agar sesuai dengan tujuan pembelajaran yang dikehendaki.

Tabel 6. Saran Validator Mengenai LKM

\begin{tabular}{|c|c|c|c|}
\hline No & Aspek yang dinilai & Catatan & Revisi \\
\hline 1 & Alur kegiatan & $\begin{array}{l}\text { LKM diberikan nomor sesuai RPP } \\
\text { nya, misalkan untuk RPP ke-1 } \\
\text { dengan menggunakan LKM ke-1 }\end{array}$ & $\begin{array}{l}\text { LKM sudah direvisi dengan mengatur } \\
\text { masing-masing RPP menggunakan } \\
\text { bantuan LKM dengan memberikan } \\
\text { kepada mahasiswa LKM satu per satu } \\
\text { selama proses penelitian. }\end{array}$ \\
\hline 2 & Kegiatan belajar & $\begin{array}{l}\text { Belum nampak pembelajaran } \\
\text { Problem Based Learning dengan } \\
\text { pendekatan saintifik }\end{array}$ & $\begin{array}{l}\text { LKS direvisi dengan memberikan } \\
\text { pembelajaran Problem Based Learning } \\
\text { dengan pendekatan saintifik }\end{array}$ \\
\hline 3 & Pemberian tugas & $\begin{array}{l}\text { Tugas di dalam LKM kurang } \\
\text { bermaknaan statistik dalam } \\
\text { kehidupan sehari-hari seperti } \\
\text { grafik perkembangan penduduk, } \\
\text { penghasilan, nilai mahasiswa, dll. }\end{array}$ & $\begin{array}{l}\text { Siswa diberikan praktik laboratorium } \\
\text { komputer untuk mengolah data dan } \\
\text { menyajikan data berupa lembar kerja } \\
\text { laboratorium kemudian mahasiswa } \\
\text { diberikan masalah yang berkaitan } \\
\text { dengan kehidupan sehari-hari untuk } \\
\text { mengolah data ukuran sepatu, nilai } \\
\text { ulangan mahasiswa. }\end{array}$ \\
\hline
\end{tabular}

Berdasarkan Tabel 2, diperoleh rata-rata nilai validasi draf 1 TKKBKM adalah 4,00 yang berarti draf 1 TKKBKM dalam kategori baik, diberikan simpulan yang valid dan dapat digunakan dalam ujicoba. Kemudian berdasarkan saran validator seperti disajikan pada Tabel 7, selanjutnya dilakukan revisi terhadap TKKBKM.

Tabel 7. Saran Validator Mengenai TKKBKM

\begin{tabular}{llll}
\hline No & Bagian yang direvisi & \multicolumn{1}{c}{ Catatan Validator } & \multicolumn{1}{c}{ Revisi } \\
\hline 1 & Isi Materi & $\begin{array}{l}\text { Substansi dari berpikir kritis yaitu } \\
\text { dalam mengemukaan analisis } \\
\text { perlu lebih jelas }\end{array}$ & $\begin{array}{l}\text { Soal dianalisis sesuai indikator } \\
\text { berpikir kritis }\end{array}$ \\
& & Pada tahapan penyelesaian sesuai & Membuat kolom baru pada kisi- \\
& & indikator kemampuan & kisi soal sesuai pedoman \\
& keterampilan berpikir kritis & penilaian soal TKKBKM \\
& & mahasiswa & Digunakan bahasa yang jelas dan \\
& & Bahasa yang digunakan harus \\
lebih mudah dipahami yang & sederhana \\
& & digunakan & \\
\hline
\end{tabular}

Setelah kegiatan validasi isi dan konstruk oleh para ahli terhadap TKKBKM maka melakukan ujicoba soal pada tes keterampilan berpikir kritis mahasiswa untuk mengetahui nilai validitas, daya pembeda, reliabilitas, serta tingkat kesukaran soal yang dilakukan di kelas C. Rekapitulasi hasil ujicoba butir soal TKKBKM disajikan pada Tabel 8. Dari 15 butir soal, 
terdapat 5 soal yang tidak digunakan yaitu soal nomor 1, 3, 4, 6 dan 13.

Tabel 8. Rekapitulasi Hasil Ujicoba Butir Soal TKKBKM

\begin{tabular}{|c|c|c|c|c|c|}
\hline No soal & Validitas & Reliabilitas & $\begin{array}{c}\text { Tingkat } \\
\text { kesukaran }\end{array}$ & Daya pembeda & Keterangan \\
\hline 1 & Tidak Valid & & Mudah & Baik sekali & Tidak Dipakai \\
\hline 2 & Valid & & Sukar & Baik & Dipakai \\
\hline 3 & Tidak Valid & & Sedang & Baik & Tidak Dipakai \\
\hline 4 & Valid & & Sedang & Baik & Tidak Dipakai \\
\hline 5 & Valid & & Sedang & Baik & Dipakai \\
\hline 6 & Valid & & Sedang & Cukup Baik & Tidak Dipakai \\
\hline 7 & Valid & Sangat tinggi & Sedang & Baik & Dipakai \\
\hline 8 & Valid & & Sedang & Baik & Dipakai \\
\hline 9 & Valid & & Sedang & Baik & Dipakai \\
\hline 10 & Valid & & Sedang & Baik & Dipakai \\
\hline 11 & Valid & & Sedang & Baik & Dipakai \\
\hline 12 & Valid & & Sedang & Baik & Dipakai \\
\hline 13 & Valid & & Sedang & Baik & Tidak Dipakai \\
\hline 14 & Valid & & Sedang & Baik & Dipakai \\
\hline 15 & Valid & & Sedang & Baik & Dipakai \\
\hline
\end{tabular}

Hasil penelitian ini didapatkan bahwa pengembangan perangkat pembelajaran problem based learning dengan pendekatan saintifik untuk meningkatkan keterampilan berpikir kritis mahasiswa dalam hal ini RPS, RPP, buku ajar, LKM dan TKKBKM didapatkan valid dengan kriteria baik. Hal ini sejalan dengan penelitian Maria (2015), dalam penelitiannya bahwa pendekatan scientific dianggap cocok untuk diterapkan sebagai alternatif pembelajaran konvensional pada pokok bahasan Pasar. Dalam pendekatan scientific lebih ditekankan kepada peserta didik untuk secara aktif dalam mengikuti kegiatan pembelajaran. Pendidik memberikan arahan kepada siswa agar mencari tahu sendiri fakta-fakta/kebenaran dalam pengetahuan yang terkait materi pelajaran yang diikuti. Selain itu berdasarkan penelitian Bungel (2014) dan Nafiah (2014) menunjukkan bahwa penerapan model pembelajaran problem based learning dapat meningkatkan hasil belajar siswa dan penerapan model PBL dalam pembelajaran materi perbaikan dan setting ulang PC dapat meningkatkan keterampilan berpikir kritis siswa dalam pembelajaran yaitu sebesar $24,2 \%$.

\section{SIMPULAN DAN SARAN}

Perangkat pembelajaran Problem Based Learning dengan pendekatan saintifik yang dikembangkan termasuk dalam kategori valid. Rata-rata nilai validasi RPS, RPP, buku ajar, LKM dan TKKBKM secara berturut-turut adalah 4,00, 4,10, 4,03, 4,01 dan 4,00. Sedangkan butir soal TKKBKM yang layak digunakan sebanyak 10 butir soal.

Adapun saran untuk peneliti selanjutnya yaitu menerapkan perangkat pembelajaran 
problem based learning dengan pendekatan saintifik pada perkuliahan untuk meningkatkan keterampilan berpikir kritis.

\section{DAFTAR RUJUKAN}

Alamsyah, N. (2016). Penerapan Pendekatan Saintifik untuk Meningkatkan Kreativitas dan Hasil Belajar Siswa dalam Mata Pelajaran IPA. Jurnal Pendidikan (Teori dan Praktik), 1(1), 81 - 88, doi: http://dx.doi.org/10.26740/jp.v1n1.p82-96.

Anjarsari, P. (2014). Pentingnya Melatih Keterampilan Berpikir (Thinking Skills) dalam Pembelajaran IPA SMP. Makalah disampaikan dalam PPM "Optimalisasi Implementasi Kurikulum 2013 dengan Workshop Pengembangan LKS IPA Berpendekatan Guided-Inquiry untuk Mengembangkan Thinking Skills dan Sikap Ilmiah Siswa", 23 Agustus 2014. Yogyakarta: FMIPA Universitas Negeri Yogyakarta.

Bruner, J. (1999). The proccess of education. diperoleh di http://edci770.pbworks.com/w/file/fetch/45494576/Bruner_Processes_of_Educ ation.pdf

Bungel, M. F. (2014). Penerapan Model Pembelajaran Problem Based Learning Untuk Meningkatkan Hasil Belajar Siswa Kelas VIII SMP Negeri 4 Palu Pada Materi Prisma. Jurnal Elektronik Pendidikan Matematika Tadulako, 2(1), 45-54

Kusuma, A. C. (2017). Efektifitas Pembelajaran Tutor Sebaya (Teman Sejawat) Berbantuan Modul Untuk Meningkatkan kemampuan Komunikasi Matematik Mahasiswa. Cakrawala Jurnal Pendidikan, 11(1), 1-8. DOI: http://dx.doi.org/10.24905/cakrawala.v11i1.649

Maria, E. I. (2015). Penerapan Pendekatan Scientific Untuk Meningkatkan Prestasi Belajar Siswa Pada Mata Pelajaran Ekonomi Pokok Bahasan Pasar. Prosiding Seminar Nasional Pendidikan Ekonomi FE UNY "Profesionalisme Pendidik dalam Dinamika Kurikulum Pendidikan di Indonesia pada Era MEA". 9 Mei 2015. Yogyakarta: UNY

Nafiah, Y., \& Suyanto, W. (2014). Penerapan model problem-based learning untuk meningkatkan keterampilan berpikir kritis dan hasil belajar siswa. Jurnal Pendidikan Vokasi, 4(1), 125-143, doi: https://doi.org/10.21831/jpv.v4i1.2540

Rochmad. (2012). Desain Model Pengembangan Perangkat Pembelajaran Matematika. Jurnal Kreano, 3(1), 59-72.

Sugiyono. (2008). Metode Penelitian Pendidikan Pendekatan Kuantitatif, Kualitatif, dan R $\odot D$. Bandung: Alfabeta. 